RICHARD K. P. PANKHURST

\title{
FOURIERISM IN BRITAIN
}

The socialism of Charles Fourier ( $177^{2-1837)}$ though primarily a French movement succeeded in exerting a not insignificant influence in early nineteenth century Britain. At first it did little more than modify the views of native pioneer socialists who imported a sprinkling of Fourierist ideas into their own writings - usually greatly modified and without acknowledgement of their origin. Gradually, however, Fourierism made more wholehearted converts and by the eighteen forties a group of enthusiastic disciples in London had succeeded in creating an embryonic movement, with mass meetings and a weekly journal. Though the movement died out after about a decade of active propaganda and even if it never achieved anything like the success it obtained in the United States (where no less than twenty-seven Fourierist communities were attempted ${ }^{1}$ ), English Fourierism produced a fairly extensive literature and undoubtedly exerted an important influence on the general pattern of English socialist thought, having in this respect a probably more significant career than the more spectacular movement of the Saint Simonians.

The following article is an attempt ( $\mathrm{I}$ ) to examine the rise of English movement, and (2) to see the kind of arguments it propounded in the British Isles, as far as possible in the original mode of presentation.

The Fourierist movement was at first on very good terms with the English co-operators. Anna Wheeler, the friend and collaborator of the pioneer British socialist, William Thompson, had met Fourier and had given him much encouragement even before his rise to fame. ${ }^{2}$ On his first reading of Owen he had been "very favourable" to the

1 Arthur Eugene Bestor, Backwoods Utopias, (r950) pp. 238-250.

2 H. P. G. Quack, De Socialisten, (1899-1904) Vol. II, p. 250; Vol. III, p. I43; Just Muiron, Transactions Sociales, p. 325. 
sage of New Lanark's theories "and also to his practical efforts". 1 Correspondence and good wishes were exchanged through the intermediary of George Skene ${ }^{2}$, as well as through Anna Wheeler who wrote to Owen when he was contemplating a visit to the continent that "the partisans of Fourier" would be "the very first" to unite with him, and that if he came to France he would be "surrounded by a strong and enlightened party." 3 It was in this mood of fraternal feeling that Owen's London Co-operative Society launched the Fourierist movement in Britain by publishing Fourier's Political Economy Made Easy, a pamphlet which argued that society at large had no idea in which direction it was advancing and that the philosophers and economists of the past so far from endeavouring to solve this problem had merely sanctioned "commercial fraud and cheating with a licensed system of general and individual lying." " The Society's Articles of Agreement (1825) were in some measure imbued with Fourierist thought.

Owenite-Fourierist friendship was however of short duration. The two movements soon became increasingly aware of their mutual differences and drew further apart; expressions of good will now gave way to denunciation and recrimination. Fourier's biographer tells us that "little by little" the French socialist came to regard the ideas of the English co-operators as "a bad and rival doctrine." 5 Accordingly in I 83 I he penned a vigorous attack on what he chose to term "the snares and charlatanism" of the Owenites and Saint Simonites. ${ }^{6}$ Borrowing a typically Saint Simonite argument he attacked the Owenites as "atheist materialists", and complained that they sought to bring about a too rapid break with the past, the more so as they demanded the impracticable ideal of equality and sought to achieve an altogether impossible transformation in human nature. He denounced the Saint Simonians, on the other hand, as not altogether disinterested advocates of false theories; they were, he declared, ambitious men who aimed to become the masters of the "sacerdotal absolutism" they proposed. Both they and the Owenites, he argued, wanted to go too fast; they deserved censure for their attacks on inheritance, religion and marriage.7 (Fourier, as "Terrence" observed in a Fourierist propaganda work later published in English, wanted religiously "to

1 Hubcrt Bourgin, Fouricr, (1905) pp. 102, 393 n.

2 Ibid, p. Io2n.

3 Richard K. P. Pankhurst, Anna Wheeler, A Pioneer Socialist, Feminist and Co-operator, Political Quarterly, Vol. XXV, No. 2, p. I 40.

4 Charles Fourier, Political Economy made easy, 1828 , p. 7 .

5 Hubert Bourgin, op. cit. p. 103.

- Charles Fourier, Pièges and Charlatanisme des deux Sectes Saint Simon et Owen, (183 I).

7 Hubert Bourgin, op. cit. pp. 180-3. 
preserve the existing conjugal institutions" for at least "three or four generations after the general establishment of harmony on earth.") ${ }^{1}$ After their break with Owen, the Fourierists felt an irresistible urge to build up a distinctive organisation in Britain. The movement had reached its apogee in France and had succeeded in winning a handful of energetic converts among British philanthropists. They were no longer content with an occasional article in the Monthly Magazine or in the Rev. Elimalet Smith's Shepherd (which serialised a translation of Abel Transon's tract on Fourier's 'Theory of Society in I 837). Nor could the New Moral World, at this time the principal organ of Owenite Socialism be considered a truly sympathetic advocate, for though serialising an extensive and seemingly impartial survey of Fourier's life and writings, it described Fourierism as a "strange and incongruous system", and declared that, whenever experience or reason failed, its author "invented from his fancy anything, however absurd, in preference to leaving the subject untouched".2 Observing that he was not a "practical man", but a student of "mathematics and mystical analogies" rather than of human nature, the newspaper devoted considerable attention to his more fantastic ideas. It ridiculed his remark that nature consisted of three eternal principles, God, matter, and science or mathematics; cast scorn on his belief that God might still create new species of living beings; and was sceptical about his declaration that the world was destined to exist for 80,000 years of which 40,000 would form a growing or improving portion, and the remaining a decreasing or decaying one. It took the view that though there was "little difference" between Fourierism and Owenism as far as fundamental doctrines of human nature were concerned, Owen was more free from dogmatism, and propounded a "far superior system" which would fully destroy the accursed "monster of competition", whereas Fourier merely sought to compromise with it, "as would the Archangel Gabriel if he parlied with his Satanic Majesty, and produced a coalition ministry".

The chief apostle of Fourierist Socialism who sought to rebut these charges was the energetic propagandist Hugh Doherty. Brought up as a Roman Catholic this Irishman had abandoned that faith for Unitarianism, from which he had "progressed to rational Deism" and later to Universalism. ${ }^{3}$ Converted to Owenism around I 830 he had been publicly defending it a couple of years later when Fourier's name was first introduced to him. As he afterwards declared, he at once lost no time in procuring the Frenchman's works and "after studying them

1 Terrence, A Short introduction to the Works of Charles Fourier, ( (1848) p. 26.

2 The New Moral World, I839, Vol. VI, pp. 609-6I 2, 834-5, 889-890, et passim.

3 The New Moral World, 1840 , Vol. VIII, pp. I $50-15$ I. 
long and deeply" had been convinced that "the problem of individual liberty and equitable repartition" was "more completely solved" by Fourier than by any other thinker. Seven years' study of the master in no wise changed that conviction; on the contrary he entered into close relations with the Fourierist leaders and by 1837 was attached to Fourier's "Commission Preparatoire" in Paris. ${ }^{1}$ He was soon afterwards appointed Fourierist emissary to Britain with special instructions to restore brotherly relations with the English socialist movement.

Doherty arrived in Leeds on May 16, 1840, to attend that year's gathering of the British socialists who met together as the "Universal Society of Rational Religionists", a name which had of course been chosen by Robert Owen who acted as president of the congress. Doherty read an enthusiastic fraternal address from across the Channel and was proud to announce that it bore the signatures of the "wellknown authoress" Flora Tristan (who sent the Congress a copy of her Promenades dans Londres), a Colonial Agent, a Captain in the English Service, several editors, Professors of Medicine and law, and "other persons of property and influence". ${ }^{2}$ The cause of socialism, he observed, was "making great progress" in France where its advocates suffered from no persecution and were "treated with courtesy by the press". He declared that though many Frenchmen were "closely identified" with the principles of the English Socialists others did not understand Owen's plans, and fancied they saw a "manifest difference" between them and those of Fourier. For his own part, after "many years of close and searching investigation", he had been "unable to discover any essential difference", and was convinced that whatever differences there might be would only be observable during what he optimistically termed the "transitional state" ahead.

Owen's "celebrated" manifesto, he concluded, had already been translated into French, and it was the intention of the Fourierists in France regularly to republish the more important articles then appearing in the New Moral World. Everyone entertaining the "great leading principles" of either Owen or Fourier should rally together under "one great banner of universal Socialism".

Each sentence of this speech was greeted with cheers and applause by the British delegates. Alexander Cambell, the Scots trade unionist, moved that all present were gratified by Doherty's "very satisfactory

1 The Shepherd, 1837 , Vol. II, p. 118.

2 The New Moral World, I 840 , Vol. VII, pp. I 314 et seq. The address bears the following signatures: F. Villegardelle, Ad. Radiguel, Jules Gay, C. Couturier, Muirson, A. Girand, Dogliani, Dufai, Christopher Frederic Guil, Charles de Ribeyrolle, J. Moussons, L. Reymoneng, Luise Vayron, Briges, C. de Lasteyrie, Henry Price, J. Borthwick Gilchrist, LL. D., R. H. Black, LL. D., Genilles, Flora Tristan, E. J. Kirwan, Lasservolle, J. Jeane, Ricourt. 
account" of the "holy cause" on the continent, and declared that "no pains should be spared" to draw closer the bonds already uniting socialists in many lands. Another delegate wished the French to know that if their message had been listened to in the "calm and business-like manner customary to Englishmen", Doherty's presence at their deliberations was nevertheless "hailed with delight". Even Owen, who a decade earlier had been so bitterly assailed by Fourier, now expressed himself "much pleased" with Doherty's address, and strongly recommended the French Socialists to appoint him their agent in England, observing that this would greatly facilitate the much desired union of the two movements. An enthusiastic reply to the French socialists was drafted, and it was unanimously decided that Doherty should be recognised as the "Deputy from the Socialists in France", and "be permitted to sit and speak in the Congress upon the same conditions as the Deputies from Yarmouth, Norwich, and Edinburgh." 1

Though the reports of Doherty's speeches are littered with references to "cheers", "hear, hear", "loud cheers" and "great applause", some of the more class conscious among the English socialists may have wondered a little to hear Doherty announce that the Fourierist meetings in France were "composed of the most wealthy, learned and influential classes", that donations from monied circles were pouring in, and that even the heir to the throne, the Duke of Orleans, was a subscriber to their publications. ${ }^{2}$ As the Rev. J. E. Smith observed, there was "a very notable distinction" between the kind of support enjoyed by the socialists in the two countries, for while in France "the very highest order of nobility did not hesitate to avow themselves friendly", in the British Isles the "social system had never been patronised or encouraged by men of education and learning". ${ }^{3}$ No cheers followed Doherty's admission that the "labouring population" of the Continent had not yet been initiated into the movement to any great extent, a failure which he attributed to the "difficulty of obtaining permission" for public lectures!

Doherty's presence was nevertheless a cause of profound satisfaction, the more so as the British movement was now on the wane and seemed in need of encouragement. The New Moral World commented that the arrival of the delegate from France was "calculated to have an important bearing upon the future destinies of the two most powerful and advanced nations of civilised Europe". It accordingly opened its

1 The New Moral World, 1840, Vol. VIII, p. 43.

2 The New Moral World, I 840, Vol. VII, pp. 1259-1 260.

3 Mary Hennell, An Outline of the Various Systems and Communities which have been Founded on the Principle of Cooperation, (1844) p. 187. 
columns to the discussion of Fourierist ideas, publishing extensive extracts from the founder's writings as well as from Doherty's expositions of them. The July issue carried a letter from the disciple announcing that he was about to tour the principal towns of the country "for the purpose of promulgating Fourier's Science of Society". ${ }^{1}$ Expressing the view that "Fourier's principles should be known in England, and that Mr. Owen's views should be known in France", he contended that he had no intention of weakening the ranks of the socialists by creating divisions of opinion, but aimed rather to "confirm the great truths of Socialism in the minds of the people by a thorough investigation of the laws of social harmony". He insisted that Fourierism did not differ from Owen in "the great principles of social economy and progressive civilisation"; it merely rejected the abolition of private property for which Owen campaigned. Fourierism believed in a future state of conscious existence and could not accept the "sceptical views" of the Owenites, though it was "not in the least alarmed at their present unbelief", being convinced that the English Socialists were "a body of practical Christians" who honestly avowed that they neither believed nor understood the scriptures, while many of the professors of Christianity appeared like "practical infidels who positively refused to act according to the doctrines which they professed". An exchange of ideas between the socialists of the two countries could not but be beneficial, the more so as the principle of equality was too exclusively inculcated in England and that of authority in France.

Fourierist controversy now burst forth in the New Moral World. A "Young Socialist" wrote a series of letters in which he enthusiastically declared that though he had been a follower of Owen before he met with the works of Fourier he was now compelled to "acknowledge the superior science" of the Frenchman, and to hail him as a French Newton and the "greatest man" that France had produced.2 On the other hand another correspondent (who signed himself "X.O." on the grounds that it would destroy his "domestic peace" if his socialist beliefs were known) bitterly attacked the Fourierist conception of a benevolent Deity, and asked how such a belief could be reconciled with the existence of injustice, war and poverty. ${ }^{3} \mathrm{~A}$ third correspondent observed that the doctrine of Fourier, as expounded by Doherty, appeared "extremely obscure" and was "quite at a loss" to understand it.4 The communist propagandist John Goodwyn Barmby, who a few

1 The New Moral World, 1840 , Vol. VIII, p. 69.

2 Ibid. p. 34I.

3 Ibid. pp. 148-9.

4 Ibid. p. 342. 
months earlier had visited France in the belief that "much was to be gained from an association of good feeling with the disciples of Fourier", returned in disillusion. He explained that he had hoped French students might have thrown new light on "the science of the social system", but that his acquaintance with the leading socialists of the country, many of whom had taken part in the revolutionary events of earlier years, had convinced him the inequalities inherent in Fourierism were "basically evil" and "a continuation of St. Simonianism", "hollow, rotten and unfruitful"; the Fourierists in Britain, he argued, were merely advocates of "quackery and charlatanism". This abuse however did not prevent Mary Hennell, a Hackney socialist, from devoting over thirty pages to the movement in her widely read Outline of the various social systems and communities which first appeared as an appendix to Charles Bray's Philosophy of Necessity in $\mathrm{I} 84 \mathrm{I}$.

In the face of hostile abuse Doherty decided on founding a propaganda organ of his own. Accordingly on October 21, I840 the Morning Star, or Phalansterian Gazette issued from the press. It was conceived as a "weekly herald of universal principles and progressive association". In it Doherty declared that the Fourierists had five practical aims:

"To secure a decent minimum of existence to the poorest individuals;

"To promote the interests of all honest classes without injuring any;

"To conciliate the established authorities by confining our operations to industry and domestic economy;

"To associate the immediate interests of both government and people, by improving the revenue in proportion to the prosperity of the labouring people;

"To benefit all branches of trade by the improvements in each, or in other words, to benefit the whole nation by every individual combination".2

Only one issue of the Morning Star was published, but it was soon followed by a much more important publication, the London Phalanx, which was founded on April 3, 184r. The prospectus of this new weekly, which guaranteed advertisers that its circulation would be "not less than 2,000 copies weekly", explained that Fourier unlike

1 Ibid. Vol. VIII, pp. 21, 6I, 74-5, 77, 327-8, 355-6, 375.

2 The Morning Star or Phalansterian Gazette, 21 October, 1840, p. 2. 
Owen aimed at "associating capital, labour and science in given proportions for the mutual interest of all", and of "awarding dividends to each" in exact proportion to their respective influences in the general production of wealth and social advantage. ${ }^{1}$ This arrangement, it claimed, would achieve "identity of interest and unity of action" without "equality of rank and community of goods" which Owen had vainly advocated. The prospectus went on to claim that Fourier's ideas, already fully developed in I 808, contained "infinitely more" understanding of human nature and a clearer understanding of the "details of social science in every degree of combination" than all the books and plans which Owen had published in forty years. Though Fourierists in England supported free trade, the repeal of the Corn Laws, extension of the suffrage, reform of the poor law, freedom of opinion, and the diffusion of knowledge, the Phalanx would remain "politically neutral", applying "Positive criticism" to all theories and opinions which appeared dangerous, whether Tory, Whig or Chartist, and would carefully avoid "the vulgar mania of railing systematically against the established Authorities in either Church or State". It would not follow Robert Owen's mistake of analysing all the various sectarian dogmas in the hope of refuting Christianity, but would abstain from religious controversy, though the editors would have it known that they were Christians following the injunction of Christ who had taught his disciples to say, "Thy Kingdom come, Thy will be done IN EARTH, as it is in HEAVEN." Fourierists were convinced however that purely political reform was no more than a "paliative policy", "absolutely inefficient and delusive"; its protagonists were "mere visionaries", who dreamt they could "renovate a worn out constitution by blistering its head and bleeding the extremes". What was needed was "to introduce a new organic principle of social progress" which would "gradually supplant the present system" as Fourier had predicted. The newspaper would accordingly concern itself with social rather than political reform, the base being "the proper point of commencement in all construction, and the apex of a destructive, or a patchwork policy". In foreign affairs it would advocate "universal association" by means of a national confederacy governed by a permanent Congress of all the civilised nations of the earth.

The Phalanx took the form of a large, important looking, weekly of sixteen pages, which was published by Doherty from $3 \mathrm{a}$, Catherine Street, just off the Strand. The Rev. James Elimalet Smith, a well known preacher of the time, was soon a frequent, though anonymous, contributor, who seems within a few months to have reached a

1 Prospectus of the London Phalanx, 184I. 
"practically ediorial position." 1 Under this editorship the journal published a Court Circular as well as sections devoted to Parliamentary Proceedings, Foreign News, and a Review of the week. Besides these un-Fourierist items there were long extracts from the master's writings; and week by week, and later month by month, the newspaper indicted capitalist civilisation whose "increasing industry", it declared, "produced increasing misery among the labouring classes". ${ }^{2}$ To emphasise the "chaos" and misery of the existing system there was a special section devoted to reports of crimes, distress and discontent, under the heading, Horrors of the Week.

In common with other Fourierists Doherty was a passionate advocate of labour-saving machinery. It is related that on one occasion he endeavoured to construct an "automaton vessel", the paddles of which would turn by the force of the wind and the waves. ${ }^{3} \mathrm{He}$ was here attempting to put into operation a then much discussed "invention" of John Adolphus Etzler, a German Fourierist, who claimed to have made a number of remarkable inventions which he described in a series of pamphlets bearing such ambitious titles as "Paradise within the Reach of All Men without Labour by Powers of Nature and Machinery" and "The New World or Mechanical System to Perform the Labours of Man and Beast by Inanimate Powers". Etzler claimed to have discovered a device by which one man would be enabled "to manage the soil in an easy, quick and certain mode, or any vessel, by the power of the wind itself". A contemporary prospectus of his "Paradise" adds:

"The waves propel the vessel, pump out the water, and do the other heavy works. The waves constitute a new motive power much superior to any of steam requiring but a cheap and simple machinery, and no fuel, nor further attendance by man beyond that of the man at the helm, applicable to the smallest as well as the greatest vessel.

"The same power may be joined to that of steam, and vessels may be propelled at the lowest average rate of twenty miles per hour.

"The same power is an infallible means to prevent shipwrecks, by driving the vessels from dangerous places under any circumstances.

"It is afforded by a new motive power (which costs nothing but a simple contrivance) of any amount desired, even of thousands

I W. Anderson Smith, Shepherd' Smith, the Universalist (1892), pp. 2 I 2-3.

2 The London Phalanx, p. 665.

3 W. Anderson Smith, op. cit. p. 2 I g. 
of horses, within the compass of fifty feet, to drive all sorts of stationary machines (mills, factories, etc.) near the coast.

Price 6d."

Etzler claimed also to have discovered how to cultivate 20,000 acres by one machine and three or four men, with a capital of less than one dollar per acre, "in the most superior mode"; how to clear land from trees, stumps, roots and stones, fill and drain swamps, make roads, and "perform any kind of work on the ground", build houses, and "furnish as much inanimate power as desired, for any place, and any stationary machine, all by the same system" !

Such claims, however fantastic they may now appear, were well received in Fourierist circles. The London Phalanx declared that "no intelligent person should be without" Etzler's pamphlet, and countered the objections of the sceptics with the tale of the man who bet a hundred pounds, and won his wager, that he would stand on London Bridge an hour and offer real sovereigns for sixpence each, without being able to dispose of one. ${ }^{1}$ Another Fourierist who optimistically urged some "plain practical mechanic" to take Etzler's drawings and make his machine to show the world what it would really be like, concluded that such "inventions" were "a marked proof of the Almighty's providential care for man".2 Fourierism and Etzlerism at this time went hand in hand; C. F. Stollmeyer addressing the Finsbury Branch of the Rational Society in the presence of Robert Owen spoke on the two subjects as one, and saw nothing irrelevant in reporting "most favourably on the progress of Mr. Etzler's great mechanical inventions" in the course of an address on "the progress of Fourierism in England, France and America". ${ }^{3}$

Besides being interested in inventions, Doherty was also a keen student of philology and the author of a popular Introduction to English Grammar on Universal Principles in which he argued that the "dry, repulsive and confused" methods of "metaphysical grammarians" were "a natural consequence of incoherence in social organisation, which aggravates all the miseries of poverty and ignorance".

This Fourieresque grammarian announced that he would lecture on Fourier gratuitously to all interested societies in or near London; from his editorial offices he distributed a wide range of propaganda works, including the Paris Phalange and the New York Future, the principal writings of Fourier, the Theorie des quatres mouvements, the

1 The London Phalanx, September I I, 184I; February I2, I842; February I9, 1842; August, 1842.

2 Minor Hugo, Hints and Reflections for Railway Travellers, (1843), Vol, I, pp. 96-7.

3 The New Age, Concordium Gazette, and Temperance Advocate, September I, I843,

p. 93. 
Nouveau Mode Industriel et Societaire, Fausse Industrie and the Traite d'Association Domestique Agricole, also the more important works of Fourierist interpretation, Just Muiron's Essai sur les Procédés Industriels and Transactions sociales religieuses et scienfiques, Jules Chevalier's Etudes sur la science sociale, Victor Considerant's Destinée Sociale, Demarche de la Politique, Manifeste de l'Ecole Societaire and Trois discours à l'Hotel de Ville, and Albert Brisbane's Social Destiny of Man and The Phalanstery or Attractive Industry and Moral Harmony. Extracts and translations of many of these works, as well as from Horace Greeley's pro-Fourierist New York Herald Tribune, were also reprinted with considerable frequency in the Phalanx. Doherty added to this literature by himself writing False Association and its Remedy and a Biography of Charles Fourier; he also arranged for the publication of a 48 page review of Brisbane's Social Destiny of Man and for English editions of Abel Transon's Attractive Industry and Madame Gatti de Gamond's Phalanstery and Fourier and his system, the translators being Mrs. Chichester and C. T. Wood. In I 843 another Fourierist disciple, Luke Hansard ${ }^{1}$, a member of the famous family of printers, issued three volumes of chatty propaganda, entitled Hints and Reflections for Railway Travellers, which evoked considerable interest, one sympathetic reviewer observing that he "should not wonder" if Hansard, who chose the nom de plume "Minor Hugo", would not "excel his elder literary brother, Victor Hugo." 2

The impact of such propaganda on an early nineteenth century Anglo-Saxon mind can best be illustrated by a graphic account by the American, Albert Brisbane ${ }^{3}$, who first learnt of the new ideology from a copy of Fourier's L'Association Domestique Agricole which he had obtained for 7 thalers from Jules Lechevalier, a leading French Fourierite convert from Saint Simonism:

"I took up the first volume carelessly and began running over the introduction; soon I came to the following phrase, printed in large type: 'Attractive Industry'. Those two words made on me an indescribable impression. In the few lines of explanation that followed I saw that the author conceived the idea of so organising human labour as to dignify it and render it attractive. I sprang to

1 In I850 we find Luke Hansard running a Committee of Christian Regenerators which held regular meetings in the Theatre of the Western Institution, Leicester Square, which were attended by Owen, Preston and other famous personalities. The motto of Hansard's society was "Do unto others as you would have them to do unto you; love your neighbour as yourself." The Family Herald, Vol. VIII, No. 365 , p. 13.

2 The New Age, Concordium Gazette and Temperance Advocate, September I, 1843, p. 93.

3 The New Moral World, (1840) p. 77. 
my feet, threw down the book and began pacing the floor in a tumult of emotion. I was carried away into a world of new conceptions." 1

Elaborating his theme Brisbane continues:

"I had studied as well as I could at my age all the philosophies of the world; and in this vast speculative realm of the human mind I had not found one new idea, one single truly original conception opening up new fields of thought. In all my studies, thus far, I had been wandering over familiar ground. I felt I knew the intellectual atmosphere of my daily existence. It was all summed up, in fact, in the theology to which I had been accustomed, and in the current maxims and views of people in general.

"Now, for the first time, I had come across an idea which I had never met before - the idea of dignifying and rendering attractive the manual labours of mankind: labours hitherto regarded as a divine punishment inflicted on man. To introduce attraction into the sphere of commonplace, degrading toil - the dreary lot of the masses - which seemed to overwhelm man with its prosaic, benumbing, deadening influence; to elevate such labours, and to invest them with dignity, were indeed a mighty revolution." 2 Brisbane's enthusiasm took him to the feet of Fourier who instructed him in his ideas for 5 francs a lesson. It was not long before the rich American was one of his most "militant disciples". Fourier's writings, he explains, "struck" him "with particular force as being entirely out of the track of accepted principles of thought". Their author's "fertile mind was full of the strangest fancies, the most farreaching conceptions on every conceivable subject in the universe"; they opened "new vistas of the social future of humanity". "There was no sphere into which he did not enter, and ofttimes with results as astonishing as they were striking in their logical appeals to the reader's common sense." 3

Fourierism, claimed Brisbane, showed that "the productive labours of mankind - those of agriculture, mining, manufactures, etc. - now so repulsive, so monotonous, so wearying to mind and body, and so degrading to those engaging in them" could "be dignified and rendered attractive". This would be achieved by "a minute division of their details, by convenient and labour-saving machinery; by healthy even elegant workshops, where a certain refinement could be introduced, and scientific thought combined with the pursuits of industry; by short sessions of labour, and the prosecution of all its branches by

1 Redelia Brisbane, Albert Brisbane, a mental Biography, (1 893) pp. 171-2.

2 Ibid. pp. 171-2.

3 Ibid. pp. 173, 187, 195 . 
groups of persons united in taste and sympathy of character, thus bringing the play of the sentiments into industry, and identifying the social and productive life of man; lastly, and perhaps most important, by a clear appreciation on the part of humanity of the importance of these labours as regards their influence on the cultivation of the globe". ${ }^{1}$ Industry, "the source of all wealth", could thus be rendered as popular as war; it could become "a path to distinction, to honour and to social position, a field in which men could display heroism and genius", every productive act being embellished with beautiful uniform, and music, "celebrated by the song of the poet, the benediction of the priest, the conferring of orders by the sovereign."

What, asked Brisbane, lay behind the Biblical curse that man must eat his bread in the sweat of his brow instead of benefiting from "attractive industry"? What was the driving force in competitive society making for misery. How, in fact, did man become rich when labour, "the source of all wealth", was "repugnant and degrading", and only obtained by the coercion of poverty and want, or by the fear of the whip? ${ }^{2}$ His reply cut to the heart of the Fourierist thesis:

"Man, socially considered, starts falsely in his career: he requires the products of labour, but he wishes to avoid its drudgery; with the falseness and duplicity of this commencement, it is easy to foresee the results which must follow. ${ }^{3}$

"If labour be repulsive, degrading, and but poorly rewarded, how are the masses to be forced to it otherwise than by constraint? Constraint is the hideous means which society has made use of to ensure production and the creation of riches; it acts with a two-fold power, one of which is the whip and punishment, the other want and privations. ${ }^{4}$

"Individual slavery, as it universally existed in antiquity, has been changed and replaced by the collective servitude of the mass." 5 "Slavery is not an isolated fact, a single blot upon our social malady, which is much deeper than supposed... That malady is repugnant industry." 6

"With the present miserable organisation of Labour, it is useless to think of general riches, that is, of abundance for all: poverty will continue to be the lot of the great majority, so long as the present defective system of industry is continued." ?

1 Ibid. p. 177.

2 Albert Brisbane, Social Destiny of Man, (1840) pp. vi-vii.

3 Ibid. p. 103.

4 Ibid. p. 104.

s Ibid. p. ros.

6 Ibid. p. 103.

7 Ibid. p. vii. 
To escape from this system seemed to Brisbane "the first problem of political economy". ${ }^{1}$ If labour could only be rendered attractive a great transformation would be achieved: "Universal employment in productive industry" would be the order of the day; idle and unproductive classes would cease to exist; the hitherto property-less and exploited labourer would be imbued with a sense of freedom and a strong incentive to work; class distinctions, which came into being when the rich sought "to acquire wealth without engaging in its laborious production" and threw the burden of toil on the masses, would come to an end. Fourierist organisation would, moreover, vastly widen the scope for scientific and intellectual pursuits hitherto the preserve of a small section of humanity. An altogether new vista was thus revealed for the human race:

"I saw", (writes Brisbane) "a healthy rich humanity organising everywhere its universities - its sources of mental development. In my enthusiasm I saw a million universities scattered over the globe, and the means of solving the great problem of human destiny.

"I saw the upper classes engaged voluntarily in productive industry, and becoming the true leaders of the world, instead of its oppressors. I saw the disappearance of that painful anomaly in human society, an intelligent class of industrial directors, living virtually in idle ease, at the expense of a vast, ignorant multitude, bent under the tiresome, falsely organised - hence repulsive-labours of our civilisation.

"I saw how the lower strata of society, which from the beginning of history had been so degraded, would gradually rise until brought up to the level of true human dignity. I saw a convergence of interests, a unity of purpose, a common aim for the elevation and happiness of mankind.

"The point that most particularly interested me was the immensely increased power that mankind would attain from the development of the sciences... With the reign of universal wealth I saw the means of the highest scientific development and leisure for millions to engage in scientific studies." 2

Another aspect of the new ideology whichevoked Brisbane'senthusiasm was Fourier's analysis of human nature. In a further outburst of excitement he proclaims the non evil nature of what he terms "the forces of the human soul - the motors which impel man to action".

"These," he declares, "have always been regarded as tending spontaneously to evil, to discord, to violence, selfishness, and

1 Ibid. p. 63.

2 Redelia Brisbane, op. cit. pp. 178-9. 
the thousand vices and crimes with which the world is rife. Why is this? Fourier answers: because they are developed under the influence of a false social order; under institutions totally unsuited to them." 1

"Our great teachers of all times - the theologians, the philosophers and the churchmen - considering actual social institutions as normal and permanent, have blamed not society but man for the disorders that reign and have reigned; hence the moral theories that have flooded the world, undertaking to adapt the human soul to short-sighted, arbitrary laws and institutions of human invention, instead of seeking to comprehend the constitution of that soul and to adapt the external environment to its nature and requirements. ${ }^{2}$

"We do not construct steam-engines according to our fancies, but to suit the demands of the force destined to act through them; we do not make musical instruments in conformity with preconceived ideas of symmetry and beauty, but in strict harmony with their requirement. If these psychical forces which Fourier calls passions produce all the discords of which society is the spectacle, it is no more their fault than it would be that of a Beethoven producing only discord with a defective instrument or a badly trained orchestra." 3

It was thus in a mood of passionate enthusiasm bred of tireless inquiry that the followers of Fourier studied the writings of the master which to not a few observers of the twentieth century situated in essentially different circumstances have appeared so bizarre and "so charged with the ludicrous" as "scarcely to be read without, intermittently, loud guffaws of uproarious and irreverent laughter." 4

Fourierism by the early I $840^{\circ}$ 's was beginning to be a force in Britain. After Doherty its next most important convert was probably Arthur Young, the son of the famous agricultural reformer of the same name. $\mathrm{He}$ it was who gave 400,000 francs to the French movement which enabled it to found its Paris daily, La Democratie Pacifique, which continued publication until its suppression by Louis Napoleon in 1852.5 In his enthusiasm Young also purchased the Abbey of Citeaux, one of the most illustrious remnants of the middle age splendours of France, at a cost of $1,300,000$ francs with the intention of transforming it into a model Phalanx on Fourierist principles. The Times in

1 Ibid. p. I8I.

2 Ibid. p. 182.

3 Ibid. p. 183 .

4 Alexander Gray, The Socialist Tradition, (1946).

5 Redelia Brisbane, op. cit., p. 194; The Spectator, October 2, 1841 . 
reporting that he planned to lay out a further million francs on the establishment of the colony, commented sarcastically that "a fool and his money are soon parted", and that he should "pay something of a high figure" for this glory. ${ }^{1}$ The New Moral World was, however, more sympathetic; it referred to Young as a "noble minded and intelligent" philanthropist, but could not refrain from adding that the Citeaux project was planned to provide him $8 \%$ interest before the labourers were allowed any profits.

Another much publicised convert was Samuel Wellwood, a Glasgow hand-loomweaver, who was so impressed by Fourierism that he wrote an open letter to the Chartist leader, Feargus O'Connor, urging the superiority of Fourierist organisation over the schemes of peasant proprietorship which O'Connor was then advocating. ${ }^{2}$ The weaver was a bitter critic of the existing system which he said obliged him to labour is or 16 hours a day in a damp and health-destroying atmosphere without earning enough to supply his family with the barest necessities of life. He declared that events since the passing of the Reform Bill had forced him to the conclusion that political reforms had not permanently elevated the condition of the labouring population. The workers, he was convinced, could not enjoy "real liberty" whilst forced to toil and drudge six days out of seven in filthy workshops or lonesome fields, and then be obliged to beg degradingly to their master for their pay. "The Problem of the XIXth century" was "not to spoliate the rich or to give the labourers a patch of land in which to dig for independent mediocracy, but to unite the interests of rich and poor in combinative industry for mutual advantage". Peasant proprietorship such as O'Connor suggested would neither terminate the exactions of merchants and capitalists nor ameliorate the wretched conditions of the labourer; these ends could be achieved only by Fourierist organisation. Doherty followed up this address, which he published as a pamphlet, by endeavouring to form an alliance or at least an understanding with the Chartist movement. His approaches were however rejected by the Poor Man's Guardian which spoke for many English Radicals when it declared its "dislike of system-making", concluding that it saw no necessity for such ideas until after the victory of the Charter when the British worker would "need neither Owenism nor Fourierism to make him independent and happy". ${ }^{3}$

Fourierist ideas were however now penetrating the general body of socialist opinion as well as evoking applause from isolated philan-

1 The Times, October 28, $184 \mathrm{I}$.

2 Samuel Wellwood, A letter to Feargus O'Connor, 1842.

3 Poor Man's Guardian, 1843 No. 8, pp. 60-I. 
thropists. An Owenite pamphlet of 1838 , entitled To the Working Class - Competitive versus Co-operative Labour was deeply imbued with Fourierist ideas. The Rev. Edmund Roberts Larken, curate of Horbling in Lincolnshire, delivered a sermon on July 24,1842 , in full support of the movement which was published in pamphlet form with an appendix on Fourier's "industrial system". F. O. Ward, a friend of Edwin Chadwick and a notable sanitary reformer, also expressed himself deeply interested. ${ }^{1}$

The Leeds social reformer, James Hole, also borrowed some of his ideas from the Fourierists, though it is significant that though advocating the essentially Fourierist "principle of association", he dissented from the master's proposals to establish "phalanxes of harmony", declaring social problems must be dealt with empirically. "The principle of Association", he said, was "susceptible of every degree of application, from the simplest assistance which two men agree to render each other, up to the highest and most refined combinations". "All the social reformer was bound to do, was to show that the ends of society were more likely to be attained by concord than by conflict, by combination than by isolation. He was by no means bound to improvise the future, to cut up mankind to pattern, and initiate society into some Owenite Parallellogram or Fourieristic Paradise." The form might best be left to time, though the doctrine should be established "as soon as possible" to demonstrate that it was "not absurd, self-contradictory or at war with the inherent tendencies of human nature". ${ }^{2}$

"While the pauper shivers in his rags and the beggar and thief ply their vocation, and while the workman is crushed beneath the wheels of the English Juggernauts, his wife drawn from the domestic hearth to toil in the factory, and his child left to grow up in ignorance, it is surely not right for the social reformer to confine his studies to the constructing of patent Systems of Metaphysics and Paper Phalansteries." 3

It was not, Hole argued, "the part of wise men to wait for the realisation of large schemes, but to seize present opportunities and make the most of them". He therefore exhorted his readers to support Working Men's Associations, Mechanics' Institutes, Co-operative Stores and other movements for social betterment, on the ground that each of them, often "unconsciously to their promoters" was "working out the parts of a great problem, the solution of which could only be achieved experimentally". In accordance with these

1 J. Pope-Hennessy, Monckton Milnes, (I 949-5 I) passim.

2 James Hole, Lectures on Social Science and the Organisation of Labour, (18 5 I), p. vii.

3 Ibid. p. viii. 
arguments he founded the Leeds Redemption Society, which, according to the People's Journal aimed at carrying out a "substantial portion of the plans of Owen, Saint Simon and Fourier". 1

The London Phalanx ceased publication in May, I 843, but Doherty announced in the last issue that a "Phalansterian Tract Society" had been instituted with himself as Secretary, James H. Young as President, and William Taylor as Treasurer. He claimed that the appeal for funds for the society had already been so successful that a large number of donations had been received varying "from one thousand to one hundred pounds, and none less than five". It was hoped that the public would give donations of from $\mathrm{I} / \mathrm{-a}$ month to $f$ ioo a year so that the society would be able to issue 50,000 or more tracts, and found a "College of Attractive Industry" where soo boys and girls between $\mathrm{I} 2$ and $\mathrm{I} 4$ would be "educated morally, religiously, industrially and artistically". Despite these high hopes there is no evidence that the College was ever founded; a series of Fourierist leaflets were nevertheless issued from the Society's headquarters at 55, Rupert Street, Haymarket, and were on sale also at P. Rolandi's bookshop in Berners Street. ${ }^{2}$

The Rev. Elimalet Smith who now "fell out" with Doherty over Fourierism and founded the Family Herald in which he criticised Doherty's too strict adherence to the founder, relates that the British disciple was at first "crestfallen" 3 by the limited success of his efforts. He urged that Doherty was "beyond the school in which he matriculated", and possessed the "power of mind and purpose of heart" to make him himself "shine in a much wider sphere than the advocacy of an individual system". 4

Doherty, however, was not to be deflected from his purpose by such arguments. John Minter Morgan, an ex-Owenite turned Christian Socialist who visited France in 1845 , reported that he had returned to Paris where he was once again in charge of the movement's "English correspondence". Arthur Young's projected Phalanx at Citeaux, Minter Morgan added, had proved an unsuccessful experiment, and there were now "not more than forty persons on the premises", though Young, whom he had met at the Hôtel du Prince, still appeared "confident of the truth of Fourier's system" and had "satis-

1 The People's Journal, i 846, p. 34 I.

2 Terrence, op. cit., p. 26.

3 W. Anderson Smith, op. cit., pp. 223, $4 \mathrm{I} 3$.

4 In later life Doherty emigrated to America, and, as Smith had urged, abandoned the advocacy of doctrinaire Fourierism, and though still deeply influenced by the master's teachings, devoted himself to wider studies in the social science, as a result of which he wrote a Philosophy of History and Social Evolution (1874), and five volumes of Organic Philosophy (1 864-78). 
factorily accounted for the recent failure", declaring that the theory of the steam engine was not disproved if village blacksmiths failed to construct one. ${ }^{1}$ Morgan was deeply impressed by Fourier's disciples and referred to them as "men of classical attainments and of extensive reading, earnest and eloquent in their exposition of existing evils, and generally respected for their good intentions and moral character"; he was not in the least surprised that their income exceeded six thousand pounds a year, or that they had sold twenty-five thousand copies of their Almanack in 1845 and expected to sell fifty thousand the following year. ${ }^{2}$

Active propaganda in Britain had now come to an end though interest in the movement continued. A certain Mr. Comists replaced Doherty as principal lecturer on Fourierism, and it was he who addressed the Co-operative Congress on that subject on May Day, I $848 .^{3}$ Fourierist writings by Doherty, Tito Pagliardi, Mary Leman Gillies and others continued from time to time to appear in the People's Journal, the Topic, the Penny Cyclopedia, the Social Science Review and the Morning Chronicle. ${ }^{4}$ The Rev. John Reynell Morell, a sypathetic critic, wrote a Sketch of the life of Charles Fourier in 1849 , and translated the French socialist's Passions of the Human Soul in two large volumes in $185 \mathrm{I}$; he also discussed him in some detail in his own History of Modern Philosophy.

Before examining the kernal of Fourierist thought, let us look at the comment it evoked.

Writing in 1848 Marx and Engels castigated Owen, Saint Simon and Fourier for fancying themselves "uplifted to a position sublimely above the class struggle", and indicted their followers in even severer language, complaining that whereas the founders of the utopian systems were "in many respects revolutionary" the disciples were "reactionary sectarians" who dreamt of "isolated phalansteries" and other "pocket editions of the New Jerusalem" while appealing to "the philanthropy of bourgeois hearts and bourgeois money bags". Such criticism in the Communist Manifesto was of particular relevance in respect of the later day English Fourierists who succeeded Doherty. By the summer of 1848 when talk of revolution was everywhere heard

1 Like Doherty, Young in due course ceased to be a mere disciple of Fourier and published such unorthodox analyses of society and human behaviour, as The Fractional Family (1864), Axial-Polarity or Man's Word-Embodied-Ideas (1887) and Sociology Diagrammatically Systematized (I 890 ), The Westminster Review, which like most readers found them rather bizarre, commented that they were "set forth in a series of strange diagrams accompanied by 'readings', in equally strange terminology."

2 John Minter Morgan, Letters to a Clergyman, (1846), pp. 13, 57, ror.

3 Herald of Co-operation, I848, p. I 52.

4 The People's Journal, I846, Vol. I, pp. 26, I 50, I67, I95, 213; 1847, Vol. II, pp. 262, 345 . 
and when many regarded the continent of Europe ripe for militant Communism, the Liberal Morning Chronicle recognized Fourierism as by far the least of the socialist evils. It observed that the movement was "directly opposed" to revolutionary communism and "in no instance ran counter to the laws of human nature or the established principles of political economy". Fourierism, it argued, merely proposed "to combine, generalise and apply on a large scale, plans, principles and modes of management" which had "already undergone the test of experience". ${ }^{1}$ The Chronicle considered a Fourierist phalanx would in many ways resemble an association of capitalists which it declared "the most appropriate mode of conducting an extensive enterprise". Though the journal was undecided whether the working class could or ought to be associated as a partner in industry, it saw "nothing alarming in the proposition", provided it was not confused with "the mischievous doctrine of Government interference" then connected with it by other socialists. Economic progress, it thought, was rendering machinery so complicated that owners of delicate equipment were afraid to trust it to any but the best and most careful workmen; to make the labourer a partner might therefore be of positive advantage to the capitalist. Fourierism was to be welcomed as much for soothing the discontent of the multitude as for endeavouring to remove slums and other evil conditions. Nor was the idea of "association" unreasonable in itself, for was it not the principle by which a relatively modest membership fee made available all the luxuries of the Atheneum or United Services Club?

Such reasoning met with little support from Mazzini at this time an emigré in London. He launched a bitter attack on all branches of socialist thought in the People's Journal. Fourierists and Saint Simonians, he contended, were both of them "atheist materialists" who had abandoned true religion and worshipped the Utilitarianism of Jeremy Bentham, thereby being led to the fatal dilemma of how to reconcile the clash of interest between the individual and society. The Saint Simonians had chosen to espouse despotism and the negation of liberty, while the Fourierists had followed the diametrically opposite road, and had tried to give the individual full and complete satisfaction at the expense of moral and spiritual values. Their powerful yet "unpitying logic" had taken them into "most impure hiding places", and in their quest of material happiness they had "broken the link between heaven and earth", even making the immoral suggestion of a stationary population (which Mazzini characterised as "Malthus crowned with roses and pressing the juice of the grapes").

"Fourierists, St. Simonians, Communists, I know you all. By

1 The Morning Chronicle, 3 I May, 1848. 
whatever name you clothe yourselves; whatever may be the formulas of universal brotherhood and love that you may borrow from democracy, and although these formula may have a real echo in your hearts - for I attack only your intelligence - you are worshippers of utility, you have no other moral than that of interests - your religion is that of matter."

Some Englishmen, he feared, might still be tempted to support the Fourierists from "fervour of inconsiderate love", but sooner or later they would be obliged to follow their master in "committing suicide upon all the noble elements of their nature" by abandoning themselves to purely material interests. Fourierists were unable to make man moral and only pandered to the "anarchy of animal propensities", merely offering the glutton nine meals a day, and the sensual the possibility of passing "from one woman to another in the papillone". What was needed, Mazzini argued, was not the greatest possible happiness, but the greatest possible nobleness; because of its lack of strong religious belief Fourierism could neither conquer the human spirit nor make any progress towards perfectioning human society; it would never succeed in organising humanity but only the kitchen of humanity - and no great architect ever started his chef d'oeuvre with the kitchen. ${ }^{1}$

John Stuart Mill, on the other hand, was deeply impressed by the essential humanity of the movement with which he was well acquainted. $\mathrm{He}$ wrote to Harriet Taylor that it was infinitely warmer than the orthodox economic thought of "pinched methodistical England" 2, and in his Principles of Political Economy he referred to the "number, talent and zeal" 3 of the Fourierists. Their ideas, he declared, were both "totally free from the objections usually urged against Communism"; "the great intellectual power" of their theoreticians and "their large and philosophical treatment of some of the fundamental problems of society and morality", such as the position of women had placed them "among the most remarkable of the past and present age". ${ }^{4}$ Fourierite socialism was above all "most skilfully combined" to "avoid all objections". ${ }^{5}$ It could not be accused of abolishing "any of the motives to exertion which exist in the present state of society". On the contrary:

"if the arrangements worked according to the intentions of its

1 The People's Journal, I 846, pp. 345-7; Richard K. P. Pankhurst, The Saint-Simonians, Mill and Carlyle (1956).

2 F. A. von Hayek, John Stuart Mill and Harriet Taylor, (195 I) pp. 136, 149.

3 John Stuart Mill, Principles of Political Economy, $188_{3}$ edition, p. I 25.

4 Ibid. pp. I 3 I-2.

a Ibid. pp. I 3 1-2. 
contrivers, it would even strengthen these motives, since each person would have much more certainty of reaping individually the fruits of increased skill or energy, bodily or mental, than under the present social arrangements can be felt by any but those who are in the most advantageous positions, or to whom the chapter of accidents is more than ordinarily favourable."

Fourierist ideas for solving "the great and fundamental problem of rendering labour attractive" were "not impracticable" and were supported by "very strong arguments", for even in capitalist society there was "scarcely any labour, however severe, undergone by human beings for the sake of subsistence" which exceeded in intensity "that which other human beings, whose subsistence is already provided for, are found ready and even eager to undergo for pleasure". ${ }^{1}$ Fourierism did "no violence to any of the general laws" of human action; it would be "extremely rash to pronounce it incapable of success, or unfitted to realise a great part of the hopes founded on it by its partisans". "The thing to be desired" was an "opportunity of trial;" Fourierist and other socialist schemes were "capable of being tried on a modest scale, and at no risk, to any except those who try them".

The English exponents of Fourierism are worthy of examination as they proclaimed the master's arguments in a rationalised form, purified of their original atmosphere of fantasy and eccentricity, for though the disciples incorporated long extracts from the founder's writings, they presented their case with a minimum of dogmatism which was able to win widespread support, one pamphlet even going so far as to declare there was "not one way alone to realise Fourier, there are hundreds". ${ }^{3}$ The Fourierists were emphatic, however, that only a complete transformation of society would eradicate the evils of the world; partial reform, however beneficial in itself, could not, they contended, "reach the root of the evil", but only "modify a social order wholly vicious in itself".

Fourierism, it is worthy of note, disavowed "resemblance to the ordinary doctrines of Political Economy" on grounds that foreshadow the historicism of Marxism. "Besides the economy of production and consumption", explained Doherty, Fourier's Science of society enabled its adepts "to divine the secret springs of humanitary progression, and the various degrees of social refinement which may be

1 Ibid. pp. I 3 I-2.

2 Ibid. p. I32.

3 The Phalanstery or Attractive Industry and Moral Harmony translated from the French of Madame Gatti de Gamond, (1841) p. 144. 
obtained by human industry in different conditions of scientific and mechanical improvement". ${ }^{1}$ A Fourierist understanding of history, argued Brisbane, revealed that the ideas of each age on such questions as Divinity and Immortality were mere "reflects, either direct or inverse, of the social conditions of the time". ${ }^{2}$

Fourierism was among the first schools of socialism to argue that the ideal society of the future would gradually, yet inevitably, emerge in the course of economic development, and that it could really only be achieved through the increased productive possibilities of an economically advanced society. Only when humanity had "sufficiently advanced in science" and had "acquired the necessary powers for creating wealth in abundance", could human genius acquire "sufficient strength to discover the laws of spiritual attraction and their natural modes of equilibrium". ${ }^{3}$ Only when humanity had "sufficiently advanced in science and industry" could it enter into "its real destiny". The "universal commotion" of the early nineteenth century was the first announcement of this "great metamorphosis" which was now at hand; it revealed that the present was "pregnant with the future".4

According to the school "human beings appeared simultaneously in different parts of the globe; in the early period of their creation they were surrounded by fine climates and luxurious vegetation. In this primitive state they lived in comparative ease, supplied with the products of nature as in the South Sea Islands." Fourierists called this first stage of spontaneous life and relative happiness, "Edenism", or "the golden age of the poets". ${ }^{5}$

They argued that subsequently an increased population, with which industry did not keep pace, caused the supply of foodstuffs to become exhausted, and an age of poverty to dawn. With poverty came the awakening of the selfish faculties, and strife to acquire the means of existence. "Then began war, based on conflicting interests, and that degeneracy which led man gradually into the savage state went on increasing concurrently with the increase of population, until at last some advanced portions of the race reached the pastoral or patriarchal state, one of semi-organisation with flocks and herds and some degree of social life." 6

Out of this stage came what Fourier called the barbaric state, when

1 Ibid. p. 279.

2 Albert Brisbane, op. cit., p. 221.

${ }^{3}$ Hugh Doherty, op. cit., p. 29.

4 Ibid. p. 75.

5 The Phalanstery, p. 4.

6 Redelia Brisbane, op. cit., pp. 252-4. 
"stable communities were formed, cities founded, and agricultural and manufacturing industry developed to a considerable extent".

During the ensuing period, however,

"industry receives a slow and gradual development, which is owing almost entirely to individual effort. It struggles against the oppression of military power, and attains by slow degrees a permanent existence and an influence in society. Its products become so important to the man of war himself, both as respects his enterprises and comforts, that he is forced gradually to respect it. The industrial or labouring classes increase in strength and intelligence, until they finally assume a position which enables them to demand and force a concession of their rights. A social transformation then commences, which progresses until society completely changes its character, and becomes entirely commercial and industrial in its spirit." 1

This was the fourth stage of social development, called civilisation, in which a regular order of society was established, laws introduced, and the arts and sciences prosecuted on a large scale.

Following and emerging out of this last order would come "Guarantism", a system of society in which "the general incoherence" and conflict of individual interests "would tend to disappear in a spirit of collectivity". This would "lead to an understanding among men for the proper adjustment of all interests both public and personal". "Guarantism" would thus be a transition stage, a sort of "semiorganisation without harmony", which would eventually lead to complete order and harmony. ${ }^{2}$

The Fourierists contended that at every stage of evolution the naive had believed there was no more change to come and that perfection had been achieved. As the nomadic disdained what he considered the galling trammels of the civilised, so did "the merely civilised contemplate with horror the prophets of Harmonic Association". ${ }^{3}$ Yet "as the city superseded the forest" and "the civilised state" the "great forest of barbarism", so would the Fourierist Phalanstery be brought forth on the ruins of existing civilisation. It was true that the Barbarian system was "revolting", because "open, direct and based upon brutal force", but it was not really so different from the civilisation which had replaced it. A Pasha levied a tax because it pleased him to extort and pillage; he did not, like his successors, search in the constitutions of Greece and Rome for theories of right and duty, but merely informed you that if you did not pay you would lose your head.

\footnotetext{
1 Albert Brisbane, op. cit., pp. 278-9.

2 Redelia Brisbane, op. cit., pp. 252-4.

3 The Phalanstery, p. viii.
} 
Though "glossed over by an appearance of equity and justice", the "injustice of Civilisation" was radically similar. ${ }^{1}$ In both societies "the producing multitude" toiled and drudged to sustain a favoured majority in ease and idleness; "the feudal baron with dependents who owed him allegiance" had merely been replaced by "the banker or capitalist surrounded with a train equally dependent and servile". ${ }^{2}$

Fourrerist propaganda in Britain presented an elaborate criticism of every aspect of existing institutions. It declared, as did the Owenites and Saint Simonians, that early nineteenth century England more than any other civilised country, revealed a "contrast of poverty and wealth, of super-abundant production and excessive privation". Trading with the whole world, and "holding the first place among nations by her intelligence, her wealth and her wonderful development of industry", the country nevertheless had "no means of satisfying the famished cries of her people". ${ }^{3}$ The privations of the destitute multitude, in many cases forced to work from fourteen to sixteen hours a day in dirty workshops and confined manufactories for a scanty subsistence, increased every day ${ }^{4}$, while at the same time new luxuries were invented for the rich, thereby tantalizing "the poor with the display of these increased means of enjoyment from which they are shut out". ${ }^{5}$

Hitherto the distribution of wealth had been such that capital and commerce, though taking "no active part in the labour of production", received "the largest share of the products of industry", while the articles produced were in the main what were required by "the caprices and fancies of the rich", by no means what was needed for "the welfare of the producer". 6 Apologists argued that the luxury demands of the rich kept the labouring classes in work: "It would seem but just", the Fourierists replied, "that the labour of the working classes should be directed, first, to the production of what is necessary to their own wants and welfare, and that their surplus labour only might be directed to the creation of luxuries". A country like Britain, possessing so vast a property and deriving from it so great an annual income, "ought not to produce one single pauper unprovided for" " ; it was inexcusable that the land "cried out for labour and capital, the pauper for work and wages, the owner of money for both", when we had them all readily available. ${ }^{8}$

1 Albert Brisbane, op. cit., p. 274.

2 Ibid. p. 279.

3 The Phalanstery, p. I 2.

4 Albert Brisbane, op. cit., p. 90.

5 Ibid.p. 89.

6 Ibid. p. 125 .

7 Minor Hugo, Hints and Reflections for Railway Travellers, (1843), Vol. III, p. 243.

8 Ibid. Vol. III, p. 133. 
Voicing the general Fourierist criticism of competitive society Luke Hansard declared the cause of the anomaly of poverty in the midst of plenty was "incoherent civilisation". All was "strife and competition, debate and ill-will"; the tree of society had "the worm of avarice" at its roots, "the blight of competition seared and shrivelled up the leaves". ${ }^{1}$ Everything was "based upon the incoherent, conflicting efforts of individuals, between whom not only no connection and combination exist, but on the contrary opposition and competition full of hatred and envy". ${ }^{2}$

"Two-thirds of the population", complained Brisbane, were mere "unproductive or negative labourers", among whom, as Fourier had shown, were included most women, as well as the whole of the idle rich, all servants, fiscal agents, customs officials, soldiers and other "bloodsuckers of productive industry". Society was nothing more than "a collection of rogues, great and small, in which the great hang the small"; 3 as the poet had said:

"Great fleas have little fleas

Upon their backs to bite 'em

And little fleas have lesser fleas;

And so ad infinitum." 4

The competitive system was to the Fourierists, as to the early Socialists generally, the cause of a thousand ills:

"Look at the mass of vice, of filth, and corruption you have heaped up to yourselves in your cities, towns and villages; to your competitive system is owing one half, (aye, and how much more?) of the horrible depravity of those places; you have been the means of crowding the inhabitants one upon another, till the very air they breathe is rendered pestilential by the process; and, as if to hasten their doom, the gin-shop, the beer-shop, and the brothel, are set up at the corners of almost every street." 5

"You resemble a number of men on a race-course, who instead of taking a clear line, and keeping out of the way of the others, at once rush pell-mell into a mass, and strive to ride one another down, thereby entirely risking the chance of any of them reaching the winning post; and if one more fortunate than the rest should pass the goal, mark the condition he is in - is he fit for another race?" 6

1 Ibid. Vol. II, pp. I 59-I62.

2 Albert Brisbane, op. cit., p. 9 .

3 Ibid. p. 377.

4 Minor Hugo, op. cit., Vol. III, p. 153.

5 Ibid. Vol. II, pp. 163-4.

6 Ibid. Vol. II, p. I6o. 
"Can we ever hope for success or prosperity, while we wilfully and knowingly allow the present system to be pursued? If we are Christians it is utterly impossible; we are perfectly aware that the factory system, the mining system, and that of our operatives generally, is one which (if invention were racked to discover a more effectual method it could not be done) must tend to ruin the people, both in body and soul." 1

The "incoherent" nature of society, exclaimed Brisbane, repeating a favourite Fourierist criticism, meant a proliforation of "isolated families, mostly without the necessary capital or credit, or the proper implements, who vie with each other in an ignorant and injudicious use and application of the soil.... The root of social incoherence is to be found in the system of separate households, or as many distinct houses as there are families, which is the essence of complication and waste." 2 Four hundred houses implied "four hundred dark holes called kitchens" in which "four hundred poor creatures must pass their time" making "four hundred monotonous meals". ${ }^{3}$ Everything had to be done on a small and niggardly scale; meat had to be cut up into tiny pieces and boxes of tea had to be broken up to be sold pound by pound.

The position of women was frightfully depressed:

"Woman in her union with man" declares Brisbane, "becomes a secondary being who is annexed to him; she loses her name, which is merged in his, and her right of action as an independent being. She owes him obedience in return for support; and so easily does the mind surrender independent reflection to predominant prejudices, that even woman herself looks upon this dependency, this abasement, as natural." 4

In the face of all these evils the Fourierists declared that it was idle to talk of civil liberty which in any case did not embrace "the entire field of human or social liberty", the economic field, but "only a secondary half", that of purely political affairs:

"If we look at the cities of Civilised Europe we see the labouring classes wandering from manufactory to manufactory, or shop to shop, inquiring for work and refused it. Without any means of existence while out of employ, pressed by want, often by starvation, they reduce the price of their day's labour, selling fourteen and more hours of monotonous drudgery out of each twentyfour for a miserable pittance." 5

\footnotetext{
1 Ibid. Vol. II, p. 166.

2 Albert Brisbane, op. cit., p. 5 .

3 Ibid. pp. 80-8 I.

4 Ibid. p. 299.

5 Ibid. p. I I 2.
} 
"Labour is the lot of the vast majority of human beings; their days are spent in it; they are constrained to toil and drudge, because stern necessity, which they would avoid, forces them to it. Labour, as carried on in civilisation, based on constraint and indirect compulsion, cannot be called Liberty! Nor is a being free who is forced to wear out his life in it, because the alternative - starvation or want - is more terrible in his eyes, than the bondage he resigns himself to." 1

The rich complained of widespread revolutionary agitation and excitement against property, but the London Phalanx replied that those who made such complaints forgot "the poor man's only property, his labour, has been undermined by a silent revolution during half a century of anarchy in trade, disguised by political economists with epithets of 'Freedom in supply and demand', and supported by class-legislation and monopoly of privilege". ${ }^{2}$ The result of this "silent revolution" was everywhere to be seen:

"If the head of the family, he who labours and earns his daily bread, dies before his children are grown up, what can become of the poor mother, without means of subsistence? And if the father and mother die, what becomes of the poor orphans?" 3 "If the worker becomes ill, if the manufactory, from some commercial crisis, ceases to work, if a discovery, useful to society, displaces the arm of the workman, his payment stops, and he falls into the most painful misery." 4

The Fourierists contended that society was obliged to build penitentiaries because it was unable to do away with the litigation, fraud and cheatery produced by the competitive system. ${ }^{5}$ Legislation was thus "occupied with the mere results and effects of the social organisation to the entire neglect of their source, that organisation itself". Prison and flogging were considered more important than education and training for work. Luke Hansard opined:

"If a poor man breaks lamps, wrings knockers off the street doors, upsets a policeman, or gets drunk, you fine him as a matter of course; and as you know you may as well usefully pump water out of a dry well, as extract money out of a poor man's pocket, you send him to the treadmill for a week, a month, or a year, according to circumstances and your own discretion, and at the end of his term of probation he comes out a ten times worse

1 Ibid. p. I09.

2 The London Phalanx.

3 The Phalanstery, p. 86.

4 Ibid. p. I2.

5 Ibid. p. 87 . 
character than when he entered; he returns to his home which he perchance finds 'empty', neither 'swept' nor 'garnished'. 'The law has been there - the bailiff has been there - his wife, his children are in the Workhouse, he turns back upon his inner house, that of his mind; there he finds awaiting at the door the spirits of self-degradation, hatred, revenge, theft, murder, recklessness, drunkenness, 'seven spirits more wicked than himself', these he takes into his house and they dwell with him, and truly it may be said, 'the last state of that man is worse than the first'." 1

Under such a system there could be nothing but "war and hatred between the classes". The rich withdrew in disgust from all intercourse with work-people and servants; an unjust suspicion was always attached to the poor man: "the more he is in want, the more certain he is of being refused aid and credit to enable him to turn his skill or labour to account." 2

The laws of the State, argued the Fourierists, had always a class bias. Even when the constitution recognised no difference between rich and poor, neither rights nor guarantees were real "except to the possessors of property." 3 There was "no justice for the poor man"; he was excluded from the making of laws, and could not undergo the expense of law-suits against a rich opponent who might if need be appeal from court to court. 4

The State rejected the "principal rights of man", education, the minimum wage, and the right to work, which alone were fundamental to the worker, and without which all other rights were "illusory"; it in fact did less to improve the welfare of the people than the selfish competitive system:

"The legislature confesses itself unable to devise means for the support of the country, or to afford any substantial or permanent aid for the evils under which the community groans.... Take the legislative enactments for the last ten years, and I do not hesitate to say that railway companies, banking corporations, insurance corporations and private capitalists have done more to benefit the country, at a time of almost unexampled distress, than the whole legislative body.... I can only tell them that in the course of one quarter of a century hence, the railway companies and joint-stock companies will govern the Government of this empire." 5 Despite this flattering comparison between the productivity of industry

\footnotetext{
1 Minor Hugo, op. cit., Vol. I, pp. I4-i s.

2 Albert Brisbane, op. cit., p. 69.

3. The Phalanstery, p. 135 .

4 Albert Brisbane, op. cit., p. 90.

5 The Phalanstery, pp. 45-6.
} 
and the inactivity of Government, the Fourierists were profoundly convinced that the rise of industrial capitalism, if allowed to continue unchecked, would produce "a state worse than that of actual slavery". Brisbane, for example, warned his readers that uncontrolled industrialism would result in a new form of feudalism:

"the feudality of the next stage of civilisation will result from the indirect acquisition of the soil. Capitalists and companies will gradually absorb it by the wealth which they acquire in commercial banking and other intermediate operations. The mass without property under this new Feudality will be collectively as dependent upon the powerful companies and great bankers who have in their possession the landed property, manufactures, etc., as were the serfs in the first Feudality, upon the Nobles." 1

Under such circumstances the future would see "an increase in servile dependency, in tyranny of capital, and in vice and fraud", particularly if, as was expected, the capitalists combined together for their own interests: ${ }^{2}$

"If the principles of association, according to Fourier, are not applied to remedy it, the large capitalists and powerful companies will coalesce, will mutually seize upon and monopolise industry by abandoning the desire of ruining each other through competition, and, while making enormous profits, will give to the workman but the sustenance of a slave. All this would replace society by a state of barbarism, by a feudality of industry, worse than the feudality of nobility, and at the same time the labourers, weary of suffering and oppression, would coalesce to renew those scenes of disorder which France and England have already witnessed." 3

Some idea of the passionate nature of Fourierist propaganda in Britain may be seen from the following paragraphs from a London Phalanx article on the "disintegration of society":

"Its members are exhausted; the sweat of agony issues from every pore; death approaches. If revolutionary tempests should galvanize this immense body, it will arise with threatening aspect, fury in its eyes, and words of hatred in its mouth, soon to fall again, more exhausted than ever, and perhaps dragging down in its fall the whole human race.

"The wound which frets society is the state of hardship weighing down the unemployed population. Our galleys are peopled by miserable wretches of whom the greater part were led to guilt

1 Albert Brisbane, op. cit., pp. 336-7.

2 Ibid. p. 287.

3 The Phalanstery, pp. 1 36-7. 
by not having had a morsel of bread to appease the tortures of hunger, a shelter beneath which to rest their wearied limbs, or clothing to protect them from the cold. Poor artificer! thou toilest through many a long day, and the reward of thy toils will barely satisfy the most pressing wants of thy family. Old man, when thine arms were vigorous, they did but earn thy daily bread - they could not secure repose for the future; and now thy hand is stretched forth in the rich man's path, imploring his pity. Little child, thy mouth calls the mother, who had not courage to make thee a cradle. Young man, thy genius is quenched by misery; thy voice, unknown, has not power to make itself heard; thy pen essays vainly to trace one more name on the scroll of fame; and thy brow seems bursting under the load of those thoughts, which are rushing in thy brain."

The message of the Phalanx was to take comfort and to abstain from revolutionary violence, for the disciples of Fourier were at hand, bringing not mere words as did the political reformers, but real happiness, "happiness for the present and happiness for the future":

"We will not proclaim to the people, (the Phalanx declared), "here are new political rights!' for we know they are not fed by electoral reforms, and that liberty for them consists in their well-being. "We come not violently to overturn the old society - we wish to remodel it peaceably. We summon every noble mind to assist us in the gigantic work of industrial reorganisation.

"We excite not the hatred of the poor against the possessors of wealth. Our words are peace; our religion, that of Christ - a law of union and fraternity. We wish to protect society from the misery of one part of its members, by the organisation of labour. "Assuredly it is a bold conception to wish to soften those terrible words of God to man, 'In the sweat of thy face shalt thou eat bread.' But should these men be called Utopians, whose system appears strange, perhaps whimsical, only because it is neither examined nor understood?... O ! if we stigmatize as Utopian those who promise the human race a futurity of happiness, what shall we cause those who would impel it to disastrous revolutions?" 1

With curiously mixed metaphor one of the Fourierists claimed that the establishment of a model community or Phalanx, would "have the effect of an electric shock, progressing gradually and transforming,

1 The London Phalanx, p. Iog.

2 The Phalanstery, p. 133. 
as by enchantment, the entire globe". ${ }^{2}$ The disciples contended, however, that the reform of society would be opposed by most of the rich, who would "cling with tenacity to the present order, fearing in their selfishness that the paltry advantages which they now enjoy, may be lost to them". ${ }^{1}$ The change, if carried out on Fourierist lines, could nevertheless be a peaceful one, "giving the necessities and comforts of life to those who are now destitute without attacking the interests of the wealthy"; otherwise there would be violent revolution in which the upper class would "fall victim to the blind hatred of the people" who would "be far from benefited by the change" which would resemble so many other "blood stained pages of history, with endless wars, revolutions and revolting crimes". ${ }^{2}$ On the other hand by establishing Phalanxes the new society would "form in the bosom" of the old "without hurting her", and the future would be born "disengaged from all the vices" of the past. ${ }^{3}$

Fourierism in Britain, as we have seen, carried with it some criticism of the rival socialist ideologies of Robert Owen and Saint Simon. Doherty, for example, contended the thought of both philosophers contained "some very sound principles", but that Owen's theories were "mixed up with the most repulsive doctrines". He declared that Owenism had "never been very thoroughly explained"; that its socalled "science of human nature" was "shallow beyond conception", that its views on property were "in absolute contradiction with the natural laws of variety and distributive equity", and that its proposals for rendering labour attractive were "far from being either clear or satisfactory" " ; though "a great number of sound notions concerning domestic economy and productive industry" could be found in the writings of the British co-operator, his analysis of religion and his advocacy of community of property were "more than unsatisfactory, if, in reality, they were what they are generally understood to be".5 The Saint Simonians, Doherty contended, had similarly offered a "sound critique of the evils of conflicting civilisation" and had made many "eloquent appeals", but they possessed "no sound principles concerning the organisation of industry; nor had they any idea of respecting individual liberty" - theirs was a "system of passive obedience to absolute authority and pontifical despotism". The American Fourierist, Parke Godwin, echoed such charges, but could not refrain from observing that "no previous school had done one fiftieth part"

1 Albert Brisbane, The Social Destiny of Man, (1846) p. $197 \mathrm{n}$.

2 The People's Journal, I 846, Vol. I, p. 150.

3 The Phalanstery, p. I9.

4 Prospectus of the London Phalanx, p. 12.

5 Hugh Doherty, op. cit. p. 8I. 
as much "to direct the attention of Europe to the awful condition of the labouring classes". 1

Thought the Fourierists were never able to attempt community building in Britain, they agreed with the Owenites on the advantages of such a policy. Doherty recalled that Fourier's "first inquiries concerning commerce" had "led him to discover the evils of incoherence and jarring individual interests", and claimed that by means of Fourierist organisation the social arrangements of production would for the first time in history be geared to the passions and inclinations of human nature. This had not been possible, he claimed, until Fourier had discovered the natural laws of God which were no more than a continuation of Newtonian physics. ${ }^{2}$ Hitherto society, unable "to discover the natural method of equilibrating the human passions", had sought "to manufacture precepts for depressing, repressing and compressing the desires of human nature":

"Not knowing how to saddle and bridle the fiery steed, so as to guide him safely, they had all agreed to break his spirit by flogging and curbing, and the only difference of opinion had been concerning the mode and extent of fettering and mutilating. Some had thought that the sensual impulses were more dangerous and required the strongest fetters; others had been more afraid of the intellectual desires, and had advised a general system of mental blindfolding." 3

Fourierists contended that human passions need not produce discord and suffering if geared to rationally conceived institutions; on the contrary their "essential destiny" was "to produce moral harmony and happiness".

Like Fourier himself the disciples proposed the establishment of a Phalanx of from $I, 500$ to $I, 800$ persons working together in a largescale corporate organisation.

The children in this community would be taught to regard work as play, and the adults to consider it a source of honour and no longer of shame. Hard work would be encouraged by fostering good-natured rivalry between different work parties, as well as by badges of merit, public applause and similar tributes. Working conditions would be transformed by the establishment of salubrious well-ventilated palaces of industry, and such unpleasant operations as could not be abolished would be undertaken by enthusiastic bands of volunteers spurred on by the general applause and acclamation of society. Everyone's work would be varied and of short duration so as to

1 Parke Godwin, A Popular View of the Doctrines of Charles Fourier, (1844) p. I 5.

2 The Phalanstery.

3 Hugh Doherty, op. cit., pp. 76-7. 
reduce monotony and fatigue to a minimum. Each work party would be composed of friends, as far as possible with similar interests, who would find pleasure in each other's company. The isolated peasant toiling laboriously for long hours in his field and the lonely workman plying his needle in a garret would both be replaced by enthusiastic bands of Fourierist workers singing joyous songs. The labour force would be sufficiently large to remove loneliness without being so large as to destroy the spirit of emulation possible in an association all of whose members knew each other. The produce of the community would be equitably divided: $5 / \mathrm{I} 2$ as a reward for labour, 4/12 for capital, and $3 / \mathrm{I} 2$ for skill, though there would not be a rigid division into classes, most members receiving remuneration under all three heads. Under such arrangements "jarring interests and heterogeneous institutions" would be reconciled in harmony like the divers instruments of a symphony orchestra. Family bonds and affections would be preserved, but selfishness and "exclusive interests" destroyed. The interest of one and all would at last be unified. Each individual would have a stake in the success of the whole enterprise, so that self-interest which had hitherto separated friends would now even unite enemies. There would be far greater stability than existed in the ordinary institutions of private enterprise, for the phalanx would be ensured of permanently capable leadership, whereas with a private company the son of an able proprietor was liable to lack the talent of his father. Labour saving facilities would be developed to the full, each phalanx being equipped with communal kitchens, central heating, a common laundry and so forth. One hundred milk-women who had hitherto wasted one hundred mornings travelling to town would be replaced by a small wheel-carriage bearing a ton of milk. Household chores would no longer be a drudgery imposed on half the human race; even the cradles in the communal crêche would be rocked by machinery twenty at a time! 1

Like the Owenites and Saint Simonians the followers of Fourier vigorously proclaimed the emancipation of women. They declared that with her liberation from the chores of the isolated household a vast new labour force would be availabe for truly productive employment; the hitherto dependent sex would receive "a high place in the general estimation, a dignified and pure position, favourable to her regeneration, and society's with hers". ${ }^{2}$ The disciples claimed that this emancipation would be of the greatest possible importance to all humanity, for "the more woman is depressed, the more she is held in subjection, in ignorance and ignominy, the more society becomes dull, stern and

1 Ibid. p. 97.

2 Ibid. p. I 8. 
prosaic". Male society in its attitude to women was governed solely by "selfishness and egotism; as a result it petrified at its core, retaining only the appearance of life". 1 The position of women was, however, the key to social progress or retrogression:

"If Barbarians were to give women their liberty, throw open their seraglios and adopt our system of exclusive marriage, they would become civilised by this single innovation. If, on the other hand, the civilised were to adopt the sale of women and seraglios, they would in turn become barbarians." 2

It was, claimed the Fourierists, the "special task of civilisation" to do away with the two "pivotal defects of barbarism" that is to say "to free Woman and free the Labourer" 3, both of which acts of liberation could be achieved by the Phalanx. History had seen the evolution of war from bows and war-clubs to the plains of Austerlitz, but the isolated household had remained scarcely unchanged though it had been instituted not as an "industrial assemblage" but for purposes of shelter and reproduction." "Shall Architecture with its marbles and granites" asked the Fourierists, "build only towers and fortifications for the purpose of destruction or palaces for the great who by violence have robbed the mass of their rights, while the multitude whom the Creator has placed upon earth to cultivate and embellish it, are left with huts and hovels which scarcely shelter them?" ${ }^{5}$ In the days of yore the Romans had crowned themselves with laurels for destroying 300,000 Cimbri at St. Remy; how much more real glory would the two armies have deserved "had they united for works of improvement instead of destruction," execting bridges over the Rhone, and raising dykes on her shores to preserve the valuable lands yearly washed away! In the Phalansterian era of the future, roads and railways would be built and torrents restrained, deserts and wildernesses would be brought into cultivation by "industrial armies", the Sahara would be fertilized, the isthmuses of Suez and Panama cut, the Pontime marshes drained. ${ }^{6}$

1 Ibid. p. 122.

2 Albert Brisbane, op. cit., pp. $275-6$.

3 Ibid. p. 293.

4 Ibid. p. I9I.

5 Ibid. p. rзo.

6 The Phalanstery, pp. I10, I $12-4$. 